\title{
Vai trò của tín ngưỡng thờ Mẫu đối với "an ninh tinh thần" của người Việt trong đời sống xã hội hiện nay (Qua khảo sát trên địa bàn Hà Nội)
}

\section{The role of Mother Goddess worship in "spiritual security" of the Vietnamese in social life nowadays (Through research in Hanoi City)}

\author{
Nguyễn Thị Thanh Mai ${ }^{1 *}$
}

${ }^{1}$ Trường Đại học Văn hóa Hà Nội, Việt Nam

*Tác giả liên hệ, Email: thanhmaivhh@gmail.com

\begin{tabular}{|c|c|}
\hline THÔNG TIN & TÓM TĂT \\
\hline $\begin{array}{l}\text { DOI:10.46223/HCMCOUJS. } \\
\text { soci.vi.16.1.1780.2021 }\end{array}$ & $\begin{array}{l}\text { Thờ Mẫu là tín ngưỡng dân gian tiêu biểu, chứa đựng những } \\
\text { triết lý nhân sinh, mang đậm bản sắc văn hoá của người Việt. } \\
\text { Trong bối cảnh xã hội hiện nay, khi con người thường xuyên } \\
\text { phải đối diện với những bất an, lo lắng, khủng hoảng, thờ Mẫu } \\
\text { đã trở thành chỗ dựa tinh thần vững chắc. Từ những nghiên cứu } \\
\text { thực địa (khảo sát, tham dự) kết hợp phương pháp nghiên cứu } \\
\text { định tính (phỏng vấn sâu), kết quả nghiên cứu khẳng định vai }\end{array}$ \\
\hline Ngày nhận: 29/03/2021 & $\begin{array}{l}\text { tro cúa tin ngường thơ Mâu đồ vớ1 "an nınh tınh thân" cua } \\
\text { người Việt hiện nay: nơi con người tìm kiếm an toàn sức khoẻ, }\end{array}$ \\
\hline Ngày nhận lại: 23/04/2021 & chữa bệnh; an toàn sinh kế, vận may trong làm ăn buôn bán; hoá \\
\hline Duyệt đăng: 23/04/2021 & $\begin{array}{l}\text { giải căn số, tìm kiếm an toàn giới, bản sắc, giới tính; điểm tựa } \\
\text { tinh thần trong đời sống hiện thực/tìm kiếm an toàn hiện sinh } \\
\text { nơi thế giới bên kia...Các thực hành tín ngưỡng thờ Mẫu cho } \\
\text { thấy sự biến đổi của xã hội Việt Nam, những vấn đề mà con } \\
\text { người đang phải đối diện. }\end{array}$ \\
\hline
\end{tabular}

Tì khóa:

tín ngưỡng, thờ Mẫu, an ninh tinh thần

Keywords:

belief, Mother Goddess worship, spiritual security

\section{ABSTRACT}

Mother Goddess worship is a typical folk belief, with human philosophies imbued with the cultural identity of the Vietnamese. In social life nowadays, when people are faced with frequent insecurities, worries, and crises, Mother Goddess worship has become strong spiritual support. From field research (surveys, participation) combined with qualitative research methods (in-depth interviews), the research findings confirm the role of Mother Goddess worship in the "spiritual security" of Vietnamese nowadays: the shelter that people look for health safety and treatment; livelihoods safety, good fortune in business; change destiny, reliefs from previous life troubles, gender, identity safety; spiritual fulcrum in real life/existential security in the afterlife ... The practices of Mother Goddess worship represent the transformation of Vietnam society and the problems that people are facing. 


\section{Giới thiệu vấn đề nghiên cứu}

Trong những năm gần đây, đời sống tín ngưỡng, tôn giáo ở nước ta đã có sự hồi sinh và phát triển mạnh mẽ. Biểu hiện là sự phục hồi, biến đổi của nhiều hình thức tín ngưỡng, tôn giáo truyền thống, sự đa dạng của các thực hành tôn giáo, lễ nghi và đặc biệt là sự xuất hiện những hiện tượng tôn giáo mới (đạo lạ) ở phạm vi rộng lớn hơn, hình thức mới lạ hơn, được thúc đẩy bởi nhiều lý do khác nhau, như sự phát triển của đời sống kinh tế, văn hóa, xã hội; những thay đổi trong chủ trương, chính sách, quan điểm, đường lối của Đảng và Nhà nước ta, bối cảnh hội nhập và toàn cầu hóa...đã khiến cho đời sống tín ngưỡng, tôn giáo của người Việt Nam hiện nay mang màu sắc mới, đa dạng và phức tạp hơn. Các hoạt động tín ngưỡng, tôn giáo được xem là một bộ phận của đời sống xã hội, đời sống văn hóa, đáp ứng nhu cầu văn hóa tình thần của con người. Đặc biệt, tín ngưỡng, tôn giáo đã trở thành nguồn lực tinh thần được trông cậy, là biện pháp "tâm lý trị liệu" để con người có đời sống hiện thực tích cực hơn, có ý nghĩa hơn. Có thể nói, trong các tín ngưỡng, tôn giáo ở Việt Nam hiện nay, thờ Mẫu là tín ngưỡng đã tồn tại từ lâu và khá phổ biến trong đời sống văn hóa của người Việt. So với nhiều tín ngưỡng dân gian khác, tín ngưỡng thờ Mẫu đã trải qua nhiều bước thăng trầm (có thời kỳ bị cấm, bị coi là mê tín dị đoan) nhưng nó vẫn âm thầm tồn tại bất chấp mọi sự đe nẹt, trong sự thành kiến và đồn thổi của xã hội. Bước vào thời kỳ đổi mới và đặc biệt sau khi được UNESCO công nhận "Thực hành tín ngưỡng thờ Mẫu Tam phủ là di sản văn hóa phi vật thể của nhân loại” vào năm 2016 tín ngưỡng thờ Mẫu ngày càng hồi sinh và phát triển mạnh mẽ, có vai trò quan trọng đối với người Việt trong bối cảnh xã hội chuyển đổi hiện nay.

\section{Góc tiếp cận, lý thuyết và phương pháp nghiên cứu}

Đã có nhiều công trình sưu tầm, biên soạn và nghiên cứu về tín ngưỡng thờ Mẫu ở nước ta từ trước đến nay, như: Đạo Mẫu và các hình thức Shaman trong các tộc người ở Việt Nam và châu Á (Ngo, 2004), Đạo Mẫu Việt Nam (Ngo, 2010b), Tín nguõng và văn hóa tín nguỡng ở Việt Nam (Ngo, 2012), Lên đồng - hành trình của thần linh và thân phận (Ngo, 2014), Khát vọng của người phụ nũ Việt Nam qua truyền thuyết Thánh Mẫu Liễu Hạnh (Pham, 1994), Đạo Mẫu và bình đẳng giới ở Việt Nam hiện nay (Vu, 2013), Đền thờ đạo Mẫu và tục đi lễ Thánh: không gian đời sống của tín đồ đạo $M a \hat{u} u(\mathrm{Vu}, 2013)$...từ nhiều góc tiếp cận như văn hóa học, nhân học văn hóa, tâm lý bệnh học - y học, giới, triết học. Các công trình nghiên cứu trên đã khảo cứu tín ngưỡng thờ Mẫu tương đối đầy đủ từ cơ sở hình thành cho đến hệ thống điện thờ, nghi thức, nghi lễ; khẳng định đặc trưng, giá trị, sự độc đáo của tín ngưỡng thờ Mẫu so với nhiều loại hình tín ngưỡng, tôn giáo khác. Tuy nhiên, những phân tích về vai trò, mối tương quan giữa tín ngưỡng thờ Mẫu với những chuyển biến trong đời sống kinh tế, văn hoá, xã hội ở Việt Nam hiện nay dưới lăng kính lý thuyết còn chưa nhiều. Chính vì vậy, trong bài viết này, từ những nghiên cứu thực địa trong nhiều năm trở lại đây, qua các cuộc khảo sát các cơ sở thờ Mẫu, tham dự các nghi thức, nghi lễ kết hợp phương pháp nghiên cứu định tính, dựa theo quan điểm của các nhà lý thuyết chức năng (đại diện tiêu biểu là Bronislaw Malinowski) tác giả phân tích vai trò của tín ngưỡng thờ Mẫu Tam phủ đặt trong mối tương quan với nhu cầu về sự an sinh xã hội, về sự tìm kiếm "an ninh tinh thần" của người Việt trong bối cảnh xã hội hiện nay (qua khảo sát trên địa bàn Hà Nội).

Để làm rõ vấn đề nghiên cứu chúng tôi tiếp cận từ góc độ văn hóa học phối hợp với các cách tiếp cận khác để có cái nhìn liên ngành, như: dân tộc học, văn hoá dân gian, xã hội học... đặc biệt là cách tiếp cận nhân học văn hóa, tâm lý học tôn giáo để có cái nhìn sâu hơn về chủ thể văn hoá (nhu cầu, niềm tin, đặc điểm tâm sinh lý...), "quan điểm của người trong cuộc" - những người đang thực hành tín ngưỡng thờ Mẫu hiện nay. Đồng thời dựa theo quan điểm của các nhà lý thuyết chức năng với đại diện tiêu biểu là Bronislaw Malinowski, bài viết tiếp cận tín ngưỡng thờ Mẫu theo hướng tìm hiểu chức năng của nó thông qua khảo sát vai trò, ảnh hưởng của tín ngưỡng này trong đời sống tinh thần của người Việt. Bên cạnh đó, dựa trên quan điểm "an ninh con người", 
“an ninh tinh thần” của Salemink (2010) nhằm làm rõ những động cơ và chủ đích của con người trong những thực hành tín ngưỡng thờ Mẫu, phân tích xu hướng vận động và biến đổi của tín ngưỡng này trong bối cảnh xã hội Việt Nam đương đại.

Nhằm có được những kết quả nghiên cứu, đề tài sử dụng một số phương pháp chính, như: tập hợp và phân tích tài liệu thứ cấp; phương pháp điền dã với các kỹ năng quan sát, tham dự, phỏng vấn sâu; phân tích, so sánh, đối chiếu... Trong đó, phương pháp điền dã là phương pháp cơ bản được sử dụng trong quá trình khảo sát thực tế tại các cơ sở thờ Mẫu, các bản hội đạo Mẫu, những người thực hành tín ngưỡng... để có được những tư liệu chân thực, phản ánh đúng thực trạng vấn đề nghiên cứu. Chúng tôi đã tiến hành khảo sát, nghiên cứu vào những thời điểm khác trong năm như dịp đầu năm, cuối năm, những ngày lễ, sự kiện liên quan... Tất cả những lần quan sát tham dự đều được ghi chép lại cẩn thận trong nhật ký điền dã. Ngoài ra chúng tôi còn tiến hành phỏng vấn sâu, nghiên cứu lịch sử, câu chuyện cuộc đời (life story) của những người trực tiếp tham gia vào các thực hành tín ngưỡng thờ Mẫu: việc họ đi hành hương, đi lễ, tham gia trở thành thành viên bản hội đạo Mẫu, việc họ mở phủ, trình đồng...để thấy rõ tâm lý, nhu cầu, mong muốn cũng như những giá trị mà họ có được khi đến với tín ngưỡng thờ Mẫu. Tư liệu phỏng vấn sâu đều được ghi âm đồng thời có sự kiểm chứng và đối chiếu bằng cách tham khảo ý kiến của nhiều người khác nhau. Sau đó được chuyển thể thành các biên bản phỏng vấn sâu qua việc gỡ băng. Đó là những tư liệu định tính có giá trị thực tiễn được trích dẫn trong bài viết. Trên cơ sở những nguồn thông tin thu thập được từ nghiên cứu điền dã, quan sát tham dự, phỏng vấn sâu, những tài liệu như thư tịch, sách báo, bài viết, tạp chí đã công bố và các tài liệu thu thập được từ cộng đồng, người nghiên cứu sẽ phân tích, diễn giải và so sánh nhằm làm sáng rõ vai trò của tín ngưỡng thờ Mẫu trong đời sống tinh thần của người Việt trong bối cảnh xã hội hiện nay.

\section{Những kết quả nghiên cứu chính}

Kết quả nghiên cứu của chúng tôi cho thấy, quyền năng của Thánh Mẫu cùng với các quan thánh dưới sự điều hành của Ngài sẽ bảo trợ cho các con nhang đệ tử và những người có căn duyên với Mẫu một sự “an định tinh thần”. Con người sẽ không còn sợ hãi, hoang mang và lo lắng bởi họ có niềm tin vững chắc rằng họ luôn được Mẫu che chở để vượt qua mọi khó khăn, có một cuộc sống tốt đẹp hơn. Trên thực tế con người thường đến với Mẫu, tìm mong sự trợ giúp từ Mẫu khi họ gặp phải những hoàn cảnh khó khăn, bất trắc, như: ốm đau, bệnh tật, làm ăn thất bát, gia đình lục đục, không có con hoặc không có quý tử, mạng sống mong manh...Bên cạnh đó, có người đến với Mẫu với mong muốn tìm kiếm một sự "bảo hiểm" cho cuộc sống của họ trong chính hiện tại và tương lai. Dù trong hoàn cảnh nào thì họ luôn tin rằng Mẫu là vị thần toàn năng, có thể đáp ứng các nhu cầu của con người. Có thể nói, tín ngưỡng thờ Mẫu như một phương thức nhằm "an định tinh thần" cho người Việt trong đời sống hiện nay trên các phương diện: tìm kiếm an toàn sức khoẻ, chữa bệnh; an toàn sinh kế, vận may trong làm ăn buôn bán; nơi con người hoá giải căn số, tìm kiếm an toàn giới, bản sắc, giới tính; tìm kiếm điểm tựa tinh thần trong đời sống hiện thực/tìm kiếm an toàn hiện sinh nơi thế giới bên kia... Các thực hành tín ngưỡng thờ Mẫu cho thấy sự biến đổi của xã hội Việt Nam, những vấn đề mà con người đang phải đối diện trong đời sống hiện nay.

\subsection{Nơi con người tìm kiếm an toàn sức khỏe, chũa bệnh}

Có thể nói, trong bối cảnh xã hội hiện nay, đặc biệt trong môi trường đô thị, ở các đô thị lớn như Hà Nội, Sài Gòn với sự phát triển nhanh chóng của nền kinh tế, sự ra đời ồ ạt của các công ty, xí nghiệp, nhà máy kinh doanh, sản xuất trong và ngoài Nhà nước, các tổ chức tư nhân góp phần thay đổi đời sống kinh tế của người Việt. Tuy nhiên, mặt trái của nó là thiếu sự kiểm định chặt chẽ, người dân phải thường xuyên đối mặt với sự ô nhiễm môi trường bởi khói bụi, chất thải... đe doạ chính cuộc sống và sức khoẻ của họ. Những năm gần đây ở Việt Nam các căn bệnh như ung thư, tiểu đường, tim mạch, huyết áp, hô hấp, tiêu hoá...trở nên phổ biến và báo động. Tất cả 
những bệnh này đều xuất hiện và kết thúc khá nhanh, không có triệu chứng báo trước khiến con người cảm thấy hoang mang, lo sợ. Họ sống trong sự nơm nớp, lo lắng bởi "thần chết" sẽ gõ cửa bất cứ khi nào. Bởi thế, nơi mà con người có thể tìm kiếm sự an tâm chính là "cửa Cha, cửa Mẹ": "Mình xin nguyện vọng của mình: thứ nhất bản gia bản ho chị em chúng con cầu được uớc thấy súc khỏe sống cho vui vẻ, gia đình hạh phúc. Việc thứ 2 xin với Mẫu là các cháu học hành sự nghiệp công danh cho xã hội được tấn tới. Việc thứ 3 người nào việc nấy việc nào cũng tấn tới. Xin làm ăn nghiêm túc chư làm ăn vớ vẩn đù̀ng xin, Mẫu chẳng cho đâu. Mẫu cho cái gì sức khỏe, sống cho vui vẻ, con cháu đoàn kết không chia rẽ, gia đình hạnh phúc, làm ăn chính đáng, đàng hoàng. Cho sức khỏe để vào cứa Cha, ra cửa Me đứng trước cửa Mẫu được như ý nguyện, sở nhu cầu” (Đ.T.B, Ba Đình, Hà Nội, 05/2020).

Hay một câu chuyện mà chúng tôi đã có dịp ghi lại trong dip điền dã "Bác L là một công chức Nhà nước đã về hưu, có bác trai cũng là cán bộ ngành Văn hoá. Tù lâu hàng tháng cứ ngày rằm, mồng một hoạc vào các dịp lễ lớn, gia đình có việc bác đều đi lễ ở một điện thò̀ tu nhân của đồng thầy M ở quận Tù Liêm, Hà Nội. Bác không có căn, không phải ra hầu Thánh nhưng bác có niềm tin vào Mẫu. Việc đi lễ thường xuyên này giúp bác an tâm, khoẻ mạnh, gia đình yên ấm, hạnh phúc" (M, T. T. Nguyen, 2020).

Bên cạnh đó, những áp lực, cạnh tranh, thách thức trong đời sống đã khiến không ít người thường xuyên sống trong sự căng thẳng, lo âu, stress kéo dài dẫn đến những "rối nhiễu về tâm lý", những căn bệnh trầm cảm, những hành động thiếu kiểm soát. Theo GS. Ngô Đức Thịnh "Trong môi trường xã hội đô thị với nhịp sống ngày một gấp gáp, với những dồn nén xã hội trên nhiều mặt, cả vật chất và tinh thần, thường là nguyên nhân tạo ra những ức chế tâm thần, khiến cho nhiều người rơi vào trạng thái tâm thần, điên loạn" (Ngo, 2017). Để giải toả những lo lắng, bất an con người đến với Mẫu như một giải pháp trị liệu tích cực, có thể giúp họ trở lại trạng thái cân bằng, hòa nhập với cộng đồng “Có nhũng lúc minh cảm thấy rất mệt mỏi, rất muốn gục ngãa, thì có một người nâng mình dậy bằng nhũng cái tích lịch sử, nâng mình dậy để mình thấy rằng, có rất nhiều các ngài bị oan ức nhu thế, chết trôi sông, bị đọa đày nhưng các ngài ấy vẫn kiên trung, vẫn oai hùng để trở thành thánh. Đấy là cái cao, mình không là cái gì so với các ngài được, nhung nhìn để hiểu được, để được truyền cho một cái nghị lục sống. Tôi đã tồn tại và vurợt lên được nhò̀ hai cái điều đó. Đến với Mẫu, cuộc sống của minh có mục đích hơn, mình có sức khỏe hơn. Sức khoẻ tốt, thì tâm hồn nó thoái mái” (N. T. H., Hàng Bạc, Hà Nội, 05/2020).

Việc đi lễ và tham gia vào các thực hành thờ Mẫu đã đem đến cho họ những an ủi, sự an định tinh thần, lạc quan vượt qua bệnh tật, niềm tin vào cuộc sống và tương lai phía trước. Họ tin rằng Thánh Mẫu đã ban cho họ sức khoẻ, sự bình an và gia ân cứu chữa cho nhiều người bị ốm đau, bệnh tật. Đồng thời Mẫu đã giúp con người vượt qua sự sợ hãi bệnh tật và cái chết, an tâm và lạc quan hơn để chữa bệnh. Bằng chứng là nhiều người khi đến cúng bái, cầu xin Mẫu sẽ cảm thấy trở nên khoẻ hơn, không lo lắng về cái chết vì tin rằng có Mẫu che chở và chữa lành. Theo Salemink (2010): “Con người sử dụng nhiều chiến lược cụ thể mang tính văn hoá để đảm bảo sức khoẻ và sự an vui của mình. Nhiều người lên đồng và những người tin theo đã tìm được phương cách đối mặt và vượt qua những vấn đề sức khoẻ (thể chất và tâm thần) và những điều bất hạnh thông qua thực hành lên đồng... Trong đời sống thực của con người, sức khoẻ và sự an lành luôn gắn kết với vấn đề an toàn thân thể, sinh kế, trao truyền và sự thoả mãn nhu cầu liên quan đến tôn giáo hoặc văn hoá".

\subsection{Nơi con người tìm kiếm an toàn sinh kế, vận may trong làm ăn buôn bán}

Sự phát triển của kinh tế hàng hóa nhiều thành phần được vận hành theo cơ chế thị trường ở Việt Nam hiện nay đã đem đến nhiều vận may lẫn cả rủi ro cho mọi tầng lớp xã hội, tạo ra sự cạnh tranh gay gắt, sự phân hóa giàu - nghèo. Với khoảng cách ngày càng rộng cùng áp lực của 
quá trình hiện đại hóa, đô thị hóa khiến cho nhiều người cảm thấy chơi vơi, bất ổn trong cuộc sống thực tại. Trong bối cảnh ấy, người Việt (nhất là những người kinh doanh, làm ăn buôn bán) phải thường xuyên sống trong cảm giác bất an do thiếu kinh nghiệm làm ăn có thể gây ra những quyết định kinh doanh sai lầm, ảnh hưởng của quy luật cung cầu, dịch bệnh, thiên tai...những rủi ro mà họ không thể lường trước được.

"H chuyên bán hàng quần áo ở chợ Ngã Tu Sở. Là một người nhanh nhẹn, năng động ngoài việc buôn bán nhũ̃ng mặt hàng phục vu cho những nhu cầu thường xuyên của người dân trong khu vục này, H còn nghe ngóng tình hình đánh nhũng lô hàng theo thời vụ. Việc này đã đem đến nhiều co hội làm ăn cho H với nguồn lợi nhuận đáng kể. Ngay đầu năm 2020 khi bùng phát dịch Corona, $H$ đã nhanh chóng nhập một lô hàng khẩu trang bên Nhật về bán với trị giá hơn 1 tỉ đồng với mong muốn sẽ xuất khẩu cả sang Trung Quốc. Nhung khi nhập về, lô hàng không đảm bảo, khách giao dịch thường xuyên với cô không lấy nũa khiến cô “dở khóc, dở cười” (M. T. T. Nguyen, 2020). ${ }^{1}$

Hay câu chuyện của chị D (Tây Hồ, Hà Nội): "Chị là người Bắc, sinh ra và lớn lên ở Hà Nội. Sau khi lấy chồng vì cuộc sống khó khăn, chị cùng chồng vào Vũng Tàu lập nghiệp. Một thời gian sau đó, công việc làm ăn khó khăn, đổ bể gia đình chị lại "khăn gói quả muớp" ra Hà Nội. Chồng chị xin vào một công ty làm kế toán thu ngân, còn chị ở nhà buôn bán. Chị làm về mỹ phẩm, chuyên bán buôn bán lẻ cho các cưa hàng trên địa bàn Hà Nội và cả các tỉnh thành lân cận. Nhurng mấy năm gần đây việc buôn bán trở nên bão hoà, hàng khó bán chị đành chuyển sang chơi chưng khoán. Thời gian đầu chị chura quen nên mất cũng nhiều, hiện nay thì đõ hơn, thi thoảng trúng một khoản cũng kha khá. Nhung chị nghĩ đó là do may rủi. Để gặp may chị lập một ban thờ Mẫu ở nhà để xin lộc Mẫu, đồng thời chị cũng rất chăm chi đi lễ, tham gia vào một bản hội đạo Mẫu ở Đội Cấn. Chị cảm thấy an tâm hơn và tin là Mẫu sẽ giúp chị” (M. T. T. Nguyen, 2020).

Đó là "những biến cố không được báo trước" luôn rình rập, có thể ập đến bất cứ lúc nào cướp đi tài sản, cuộc sống của họ. "Sự bươn chải trên thị trường đã chuyển đổi cuộc sống của họ, gây ra sự trục trặc, một cảm giác bất lực và cảm giác bị kiểm soát bởi các lực lượng xã hội xa xôi, mạnh mẽ và vô hình" (Salemink, 2010). Theo Salemink (2010): "Điều thực sự mang lại cảm giác dễ tổn thương và bất an kinh tế sâu sắc chính là ảnh hưởng của các lực lượng thị trường hay thay đổi hoặc những quyết định kinh doanh sai lầm không giải thích được, những tác động diễn ra mà không thể nhận thức hoặc dự đoán được". Để giảm thiểu đi nỗi lo lắng thường trực đó, họ tìm đến với Mẫu với niềm tin rằng quyền năng của Ngài sẽ giúp họ không phải đối diện với những biến cố khủng khiếp có thể xảy đến. Các hình thức đi lễ, vay tiền, mở cung tài, khai cung lộc, trình đồng mở phủ đã trở thành một phương thức hữu hiệu để tạo dựng và củng cố niềm tin vào sự trợ giúp của các Thánh Mẫu trong công việc làm ăn. Trong đó, nghi lễ lên đồng đóng một vai trò quan trọng trong việc tạo ra an toàn kinh tế trong quan niệm của những người tin theo - tức là những khách hàng.

Việc đi lễ Mẫu đã tạo ra sự an toàn kinh tế, tăng cường sự quyết đoán cần thiết và niềm tin vào thành công của công việc kinh doanh dựa trên niềm tin vào những "ân phước được Thánh ban cho". Điều này có thể thấy qua việc vay tiền - trả tiền của giới kinh doanh. Họ cho rằng việc vay tiền từ các Mẫu - lộc Thánh ban để làm ăn sẽ đem lại cho họ công cuộc làm ăn suôn sẻ, thuận lợi. Do đó, khi công việc kinh doanh thành công bao giờ họ cũng không quên trả lễ (thậm chí nhiều hơn số tiền vay) với niềm tin rằng Thánh Mẫu chính là chủ kho tiền, chủ nhà băng, là người giữ tiền, cất tiền và phù trợ cho họ trong công việc làm ăn kinh doanh (cho họ vay để làm ăn). Ngoài ra, họ tin rằng Mẫu giúp đỡ họ làm ăn khi mất phương hướng, khi chuyển đổi nghề nghiệp hay mặt hàng kinh doanh. Do đó, đa phần những người làm ăn buôn bán, giới kinh doanh, chủ doanh nghiệp có niềm tin vào sự phù trợ của Mẫu. Họ tin rằng nếu họ tin, thỉnh cầu thì sẽ "xin gì được nấy". 


\subsection{Nơi con người hóa giải căn số, tìm kiếm an toàn giới, bản sắc, tôn giáo}

Trong số những người đến với Mẫu, phần đông là những người có “căn số". Theo giải thích của GS. Ngô Đức Thịnh, “căn ở đây có nghĩa là căn quả, là số phận đã định cho một người số người phải ra hầu Thánh hay nói một cách khác họ có “căn cao số đầy” (Ngo, 2014). Có người có căn số nhẹ, có người có căn số nặng. Người nào có căn nhẹ thường sẽ phải đội bát nhang, mở phủ (nếu muốn) hoặc tiến mã trả nợ, làm lễ tiễn căn để giải thoát căn số, hy vọng quãng đời về sau không bị Mẫu “đày”, cuộc sống vui vẻ, tốt đẹp, làm ăn suôn sẻ hơn. Nhưng với những người có căn nặng, họ sẽ phải mở phủ, trình đồng và sau đó hoặc là lập điện thờ Mẫu ở trong nhà hoặc là đi lễ Mẫu ở các đền phủ khác, phục vụ nhà Thánh. Theo những phỏng vấn mà chúng tôi thực hiện thì trong phần lớn các trường hợp những người có căn đồng, bị cơ đày (điên loạn, ốm đau, làm ăn thất bát...), sau khi làm lễ mở phủ, trình đồng hoặc là lập điện thờ Mẫu (với những người có căn nặng), đa phần họ đều được giải toả, khỏi bệnh, cuộc sống trở lại bình thường, tái hoà nhập cộng đồng, thoát khỏi bế tắc, mọi việc hanh thông, gia đình êm ấm, hòa thuận. "Từ khi ra mở phủ, trình đồng cuộc đời của chị đã "khấm khá lên rất nhiều” (N.T.G, Hàng Buồm, Hà Nội); "Việc ra hầu đồng giúp minh cảm thấy nhẹ nhõm, thoải mái khi được trọ giúp về tâm lý, tinh thần, súc khoẻ, công việc đồng thời được Thánh ban lộc" (H.M, Ba Đình, Hà Nội); "Sau vấn hầu N cảm thấy thoải mái, sảng khoái, phấn chấn, mãn nguyện, căn số giảm bớt (dù có thể mệt về co thể nhung sảng khoái về tinh thần) (M. T. T. Nguyen, 2020).

Rõ ràng việc đi lễ Mẫu và hầu Mẫu sẽ giúp họ "hoá giải căn số”, mọi vấn đề gặp phải được thuyên giảm hoặc chấm dứt. Không những vậy họ yên tâm hơn vì trong cuộc đời họ "có thêm một sự bảo hiểm nữa - một sự bảo hiểm vô hình nhưng lại có thể hiện diện ở bất kỳ đâu, bất kỳ chỗ nào và theo suốt cuộc đời của họ, điều này cũng khiến cho các cá nhân trở nên thanh thản, thoải mái hơn" (M. N. Nguyen, 2013).

Bên cạnh đó, khi có "căn số” có rất nhiều người vì nỗi sợ/cảm giác khác biệt với cộng đồng về mặt tâm sinh lý, giới tính, tôn giáo, bản sắc khiến họ tự ti, mặc cảm, cô độc bởi sự xa lánh, bị "lề hoá", kỳ thị của những người xung quanh. Họ thường bị rơi vào trạng thái cô đơn, đau khổ, tự ti, dần dần họ sống khép mình, mặc cảm, không muốn giao tiếp, ít mối quan hệ, khó khăn trong việc tìm kiếm những người cùng quan điểm, lối sống và thực sự hiểu mình. Điều này gây ảnh hưởng ít nhiều đến tâm lý, động cơ hành động của họ bởi nếu không vượt qua được rất có thể họ bị rơi vào trầm cảm, tìm đến cái chết. Và trong lúc bế tắc, khủng hoảng cùng với nguyên do "căn số" của mình, họ tìm đến với Mẫu - không gian, môi trường mà họ có thể được là chính mình, sống thật với giới tính của mình, gặp gỡ những người "cùng cảnh ngộ", cùng "cộng cảm" với những sinh hoạt văn hoá tâm linh mang tính trị liệu. Các không gian, tổ chức thờ Mẫu cùng các nghi lễ đã trở thành những sinh hoạt văn hoá tâm linh mang tính trị liệu cho con người trong bối cảnh xã hội hiện nay. "Thực hành nghi lễ lên đồng đã tạo cho họ môi trường để họ tự tin và giúp họ lấy lại thăng bằng về tâm lý. Sống và sinh hoạt tập thể giữa những con người cùng cảnh ngộ đã giúp họ vượt lên những thiếu hụt của số phận” (M. N. Nguyen, 2013).

"Tù̀ khi ra trình đồng và trở thành đệ tư của đồng thầy $H$, hàng ngày giúp việc cho thầy, gặp gỡ và giúp đỡ nhũng người nhu mình tôi cảm thấy vui hơn, cuộc sống có ý nghĩa hơn. Thích nhất là việc tôi không phải tìm cách che giấu giới tính thật của mình nữa, được sống là chính mình và tìm kiếm được môi trường an toàn cho bản thân” (L.T.N, 52 tuổi, Hà Đông, Hà Nội).

"Gần 30 năm em luôn mang trong mình sự tụ ti, mặc cảm là "sản phẩm lỗi” của bố me em. Nhung tù khi gia nhập và làm con nhang đệ từ của Mấ em cảm thấy nhu tìm được thế giới của chính mình. Mối lần hầu Thánh là một lần em được mọi người đề cao, tôn trọng và nhũng tổn thuơng trước đây của minh được xoa dịu rất nhiều” (P.M.H., Kim Mã, Hà Nội). 
Bên cạnh đó, việc tồn tại tư tưởng “trọng nam khinh nữ” ở nước ta đã tạo ra những bất bình đẳng trong các mối quan hệ. Vì vậy, khi đến với Mẫu người phụ nữ có cơ hội để khẳng định vai trò giới của mình. Theo quan sát của chúng tôi từ các buổi khảo sát thực địa (tại phủ Tây Hồ, đền cây Quế, một số điện thờ tư nhân, bản hội), các tín đồ đạo Mẫu vẫn chủ yếu là nữ giới (bên cạnh những người làm ăn buôn bán, tiểu thương tiểu chủ và cả giới trí thức, văn phòng, chủ doanh nghiệp, phu nhân các chính trị gia...). Họ đến với Mẫu vì nhiều lý do, hoàn cảnh khác nhau nhưng đều chung một nỗi niềm: sự đau khổ, trục trặc trong công việc và cuộc sống. Như vậy, ở một khía cạnh nào đó, tín ngưỡng thờ Mẫu đã khẳng định vị thế của người phụ nữ trong một cấu trúc xã hội phụ quyền. Bởi bản chất của tín ngưỡng này là đề cao, tôn vinh vai trò và vị thế của người phụ nữ. Khi đến với Mẫu, được "hoá thân” vào các vị Thánh Mẫu, các vị Thánh trong thờ Mẫu, người phụ nữ như cởi bỏ được nỗi lòng của mình, sự bất bình đẳng trong gia đình. Nói như GS. Ngô Đức Thịnh họ đã được "thay đổi thân phận", được nói lên tiếng nói của chính mình.

Bên cạnh sự an toàn về giới, hiện nay có nhiều người đến với Mẫu còn bởi họ mong muốn tìm kiếm những người "cùng hội, cùng thuyền" trong cùng hoàn cảnh. Như chúng tôi đã phân tích ở trên, những người có đặc điểm tâm sinh lý đặc biệt, có lối sống khác biệt, "chẳng giống ai" thường cảm thấy cô đơn, lạc lõng và không biết nói cùng ai. Chính vì vậy, họ sẽ thường tìm kiếm những người cùng cảnh ngộ, cùng thể trạng tâm sinh lý, những tổ chức mà ở đó họ được là chính mình. Cho dù hoàn cảnh xuất thân có khác nhau, tình trạng kinh tế và vị thế xã hội có thể chênh lệch nhưng niềm tin tôn giáo vào đấng thiêng đã xoá đi khoảng cách xã hội và tạo ra cho họ chỗ đứng bên cạnh nhau, chia sẻ và hỗ trợ nhau trong những thực hành nghi lễ và ngoài cuộc sống. Hiện nay, ở Hà Nội có rất nhiều các bản hội tư nhân như bản hội Phúc Minh Từ, bản hội đền $\mathrm{H}$ của cậu Hạ, bản hội cô Chín, bản hội cô Vân...và cả những tổ chức công như Hội Di sản Văn hoá Thăng Long Hà Nội, Sở VHTT \& DL Hà Nội, Trung tâm Nghiên cứu và Bảo tồn văn hóa tín ngưỡng Việt Nam (thuộc Hội Di sản Văn hóa Việt Nam) thành lập 2008, CLB Bảo tồn Văn hóa đạo Mẫu Việt Nam (2008) với hơn 500 hội viên từ các địa phương Bắc Trung Nam đóng trụ sở tại Hà Nội, CLB Bảo tồn nghệ thuật chầu văn Việt Nam (2012), CLB Văn hóa thờ Mẫu và Hát văn Hà Nội ...Các bản hội đạo Mẫu cùng những sinh hoạt văn hoá tâm linh đã trở thành "ngôi nhà chung" cho các tín đồ đạo Mẫu, các con nhang đệ tử khiến họ không còn cảm thấy cô đơn, lạc lõng. Đó dường như là "chốn tổ”, là nơi họ thuộc về, nơi họ được yêu thương, tương trợ, có điều kiện giao tiếp, tham góp công sức vào những công việc chung của cộng đồng, cùng trao truyền những giá trị văn hoá. Điều quan trọng hơn là họ đã tìm được môi trường "cộng cảm”, gặp được những người “đồng đạo" để cùng nhau thực hành các nghi lễ̂ tâm linh, để cùng nhau đi lễ̂ xa đến các trung tâm thờ Mẫu.

\subsection{Nơi con người tìm kiếm điểm tụaa tinh thần trong đò̀i sống hiện thục/tìm kiếm an toàn hiện sinh nơi thế giới bên kia}

Theo GS. Ngô Đức Thịnh, điều đặc biệt trong tín ngưỡng thờ Mẫu là nó rất hiện sinh: hướng niềm tin của con người vào đời sống trần thế hơn là những vấn đề của thế giới bên kia/thế giới sau khi chết. Theo khảo sát của chúng tôi, cũng có rất nhiều người đến trước cửa Mẫu để cầu an, sám hối, giải hạn, mong thoát khỏi những vận hạn trong cuộc sống. "Chị người gốc Lai Xá, lấy chồng làng Lưu Xá nhưng hiện nay sinh sống ở khu vực Cầu Giấy, Hà Nội. Chị làm quản lý một quán hát karaoke. Hàng tháng chị thuờng xuyên đến lễ tại đây, nhất là vào nhũng dịp lễ lớn trong năm. Việc quan trọng thì ngày bình thường chị cũng đi kêu lễ. Khi đến lễ trước tiên là cầu sức khỏe bình an, cầu buôn bán thuận lợi. Năm nay bố thằng cu hạn nặng nên ra đây kêu xin" (M. T. T. Nguyen, 2020). 
Nhằm đáp ứng những nhu cầu cho đời sống hiện tại người Việt đã tìm đến Mẫu với tư cách là vị thần bảo hộ sức khỏe, công danh, sự nghiệp, kinh doanh, buôn bán và đáp ứng mọi mong muốn, nguyện vọng của họ. Điều mà Salamin (2010) gọi đó là "tìm kiếm an toàn hiện sinh" thông qua việc kết nối với người mất và tìm kiếm di hài người mất (tìm mộ) thông qua nghi lễ đặc biệt và năng lực của những người được coi là "con của Mẫu" (các ông đồng, bà đồng). Các ông đồng, bà đồng (con của Mẫu) đã tham gia khá đắc lực vào công việc này - những người mà sau khi hầu Thánh họ sẽ có linh hồn chuyển gia với khả năng tiên tri về tâm linh, xuất nhập hồn.

"Với tâm làm việc thiện và đặc biệt là năng lực tâm linh trong việc gọi hồn, tìm cốt người âm, cô đồng L có khá nhiều khách trong làng, ngoài làng, các vùng lân cận và ở các tỉnh thành khác đến nhò̀. Với khả năng có thể nhìn thấy, tiếp xúc với người âm, cô đồng L thuờng giúp các gia đình có thể gặp được người đã mất, nói chuyện với họ. Sau khi lên hương, hỏi rõ tên tuổi, địa chỉ, ngày mất, nơi mất, cô đồng L sẽ gọi hồn người mất lên. Cô đóng vai trò trung gian để cho nguời âm nhập vào và nói chuyện với nguoòi trong gia đình. Trong một số lần khảo sát tại điện thờ của cô L, tôi đã được chứng kiến nhiều cuộc gọi hồn, cuộc gặp giữa người sống và người đã mất" (M. T. T. Nguyen, 2020).

“Gia đình ông L ở Tây Xá, Mê Linh, Hà Nội có người em trai bị mất trong thời chiến tranh loạn lạc (năm 1954) nay không biết đang ở đâu. Điều này khiến cho gia đình ông cảm thấy không yên lòng và muốn tìm mộ để về chôn cất cho chu đáo. Ông đã đến gặp và nhò̀ cô đồng $V$. Cô đồng $V$ nhận lời giúp. Sau một thời gian lần mò địa bàn nơi em trai ông chiến đấu ngày xura cô đồng $V$ đã chỉ chỗ nằm của em trai cô. Gia đình đến tìm kiếm và quả thực đã tìm thấy..." (M. T. T. Nguyen, 2020).

Với người Việt, việc "chết mất xác" vừa là nỗi đau, sự lo âu của các thành viên trong gia đình. Ngoài lý do tâm lý (lo âu, áy náy, bất an), văn hoá (không trọn hiếu nghĩa), xét ở phương diện khác, việc chưa hoàn thành công việc tâm linh còn khiến cho các thành viên trong gia đình cảm thấy lo lắng bởi có thể sẽ ảnh hưởng xấu đến cuộc sống của họ: sức khoẻ, ốm đau, bệnh tật, bất lợi trong cuộc sống, hạnh phúc gia đình...Họ sợ rằng khi người mất chưa được chôn cất chu đáo linh hồn sẽ lang thang, đói khát, không nơi trú ngụ sẽ quở trách và trừng phạt con cháu. Do đó, việc tìm kiếm hài cốt của người mất tích vừa là trách nhiệm vừa là nghĩa vụ của người sống vừa có có ý nghĩa thiêng liêng và quan trọng. Họ tìm đến với Mẫu và mong được trợ giúp từ các ông đồng, bà đồng "Gia đình ông L ở Tây Xá, Mê Linh, Hà Nội có người em trai bi mất trong thời chiến tranh loạn lạc (năm 1954) nay không biết đang ở đâu. Điều này khiến cho gia đình ông cảm thấy không yên lòng và muốn tìm mộ để về chôn cất cho chu đáo. Ông đã đến gặp và nhò̀ cô đồng $V$. Cô đồng V nhận lời giúp. Sau một thời gian lần mò địa bàn nơi em trai ông chiến đấu ngày xua cô đồng $V$ đã chi chố nằm của em trai cô. Gia đình đến tìm kiếm và quả thực đã tìm thấy... (M. T. T. Nguyen, 2020). Nhờ đó, những người sống cảm thấy an tâm, thanh thản, nhẹ nhõm khi nỗi lo đã được giải tỏa - một sự "an định tinh thần" nơi cuộc sống thực tại.

\section{Kết luận}

Thờ Mẫu với tính ưu việt của nó (mang đậm tính hiện sinh, hướng đến cuộc sống thực tại của con người với những ước vọng về sức khoẻ, hạnh phúc, tài lộc, may mắn...) đã trở thành chỗ dựa/điểm tựa tinh thần vững chắc, đóng vai trò quan trọng trong đời sống tâm linh cho người Việt trong bối cảnh xã hội chuyển đổi hiện nay. Những bất ổn trong cuộc sống vật chất cũng như tinh thần khiến cho nhu cầu về sự an sinh xã hội, về sự tìm kiếm "an ninh tinh thần" của người Việt lớn hơn bao giờ hết. Trong bối cảnh đó, họ tìm đến với Mẫu nhằm "an định tinh thần", vượt qua nỗi sợ hãi và những khủng hoảng của cuộc sống, tìm kiếm sự cân bằng, giải toả lo lắng. 
Từ những nghiên cứu khảo sát điền dã, với phương pháp phỏng vấn sâu được áp dụng chủ yếu, bài viết khẳng định thờ Mẫu đã trở thành nơi mà người Việt có thể tìm kiếm an toàn sức khoẻ, chữa bệnh; an toàn sinh kế, vận may trong làm ăn buôn bán; nơi con người hoá giải căn số, tìm kiếm an toàn giới, bản sắc, giới tính; tìm kiếm điểm tựa tinh thần trong đời sống hiện thực/tìm kiếm an toàn hiện sinh nơi thế giới bên kia. Đồng thời, các thực hành tín ngưỡng thờ Mẫu cho thấy sự biến đổi của xã hội, những vấn đề mà con người đang phải đối diện.

Tín ngưỡng thờ Mẫu qua nhiều chặng đường gian truân trong hành trình tồn tại và phát triển cho đến ngày nay đã cho thấy vị trí của nó trong đời sống tinh thần của người Việt. Tuy nhiên, trong bối cảnh xã hội hiện nay, thờ Mẫu đã và đang có nhiều biến đổi theo chiều hướng tích cực và tiêu cực. Bên cạnh những giá trị tích cực, hiện tượng mê tín dị đoan, buôn thần bán thánh, tính thương mại hoá khiến những giá trị thiêng liêng của tín ngưỡng này đang bị biến tướng, sai lệch. Vấn đề đặt ra là Nhà nước và cộng đồng cần có sự đồng thuận, phối kết hợp trong việc nâng cao nhận thức của người dân về những giá trị đích thực của tín ngưỡng, giữ gìn và bảo vệ di sản của dân tộc.

\section{Tài liệu tham khảo}

Hội Di sản Văn hóa Thăng Long. (2017). Thực hành tín ngưỡng thờ Mẫu Tam phủ trên địa bàn Hà Nội - Nhận diện, bảo tồn và phát triển [Practice the worship of Mau Tam phu in Hanoi Identify, preserve and develop]. Kỷ yếu Hội thảo khoa học, 47.

Ngo, T. D. (2004). Đạo Mẫu và các hình thức Shaman trong các tộc người ở Việt Nam và châu Á [Motherhood and Shamanic forms among ethnic groups in Vietnam and Asia]. Hanoi, Vietnam: NXB Khoa học Xã hội.

Ngo, T. D. (2010a). Bảo tồn, làm giàu và phát huy các giá trị văn hóa truyền thống Việt Nam trong đổi mới và hội nhập [Preserve, enrich and promote traditional cultural values of Vietnam in innovation and integration]. Hanoi, Vietnam: NXB Khoa học Xã hội.

Ngo, T. D. (2010b). Đạo Mẫu Việt Nam (tập 1, 2) [Vietnamese Motherhood (episodes 1, 2)]. Hanoi, Vietnam: NXB Tôn giáo.

Ngo, T. D. (2012). Tín nguõng và văn hóa tín nguõng ở Việt Nam [Beliefs and cultural beliefs in Vietnam]. Hanoi, Vietnam: NXB Trẻ.

Ngo, T. D. (2014). Lên đồng - Hành trình của thần linh và thân phận [To the field - the journey of spirit and condition]. Ho Chi Minh, Vietnam: NXB Trẻ.

Ngo, T. D. (2016). Đạo Mẫu trước xu hướng hiện đại hóa [Dao Mau before the modernization trend]. In Kỷ yếu Hội thảo khoa học quốc tếnghiên cúu thục hành tín nguỡng thờ Mẫu trong xã hội đương đại (Trương hợp tín nguõng thò Mẫu) [Proceedings of the international scientific conference research on the practice of Mau worship beliefs in contemporary society (The case of Mau worship beliefs) (p. 218). Hanoi, Vietnam: NXB Thế giới.

Nguyen, M. N. (2013). Nghi lễ lên đồng lịch sủ và giá trị [Ritual to co-history and value]. Hanoi, Vietnam: NXB Văn hóa Thông tin.

Nguyen, M. T. T. (2020). Nhật ký điền dã các đền phủ thờ Mẫu tại Hà Nội năm 2020 [Diary of the Mau temples in Hanoi in 2020]. Hanoi, Vietnam: Tài liệu lưu hành nội bộ.

Pham, P. Q. (1994). Khát vọng của người phụ nữ Việt Nam qua truyền thuyết Thánh Mẫu Liễu Hạnh [The aspiration of Vietnamese women through the legend of Thanh Mau Lieu Hanh]. Tạp chí Khoa hoc về phu nũu, 4, 4-5. 
Salemink, O. (2010). Tìm kiếm an toàn tinh thần trong xã hội Việt Nam đương đại [Seeking spiritual security in contemporary Vietnamese society]. In Hiện đại và động thái của truyền thống ở Việt Nam: Nhũng cách tiếp cận nhân học [Modernity and dynamics of tradition in Vietnam: Anthropological approaches] (pp. 1-22). Ho Chi Minh, Vietnam: NXB Đại học Quốc gia thành phố Hồ Chí Minh.

Vu, A. T. T. (2013). Đạo Mẫu với vấn đề trao quyền lực và cách thức sử dụng quyền lực của người phụ nữ Việt Nam [Dao Mau with the issue of empowerment and how to use the power of Vietnamese women]. In Văn hoá thờ nũ thần - Mẫu ở Việt Nam và châu Á, bản sắc và giá trị [Goddess worship culture - Model in Vietnam and Asia, identity and values]. Hanoi, Vietnam: NXB Thế giới.

Vu, A. T. T. (2013). Đền thờ đạo Mẫu và tục đi lễ Thánh: Không gian đời sống của tín đồ đạo Mẫu [Mothers'shrine and the custom of going to Holy Mass: The Mother' life space]. Tap chi Văn hóa dân gian, 5(143), 13-23. 